\title{
IMPORTANCE OF CROP PRODUCTIVITY AND EQUIPMENT LIFETIME IN THE STRATEGIC AND TACTICAL MANAGEMENT OF SUGARCANE HARVESTERS
}

\author{
Ângelo D. Banchi ${ }^{1 *}$, Angel P. Garcia ${ }^{1}$, Daniel Albiero' ${ }^{1}$, Cezário B. Galvão ${ }^{1}$, Luis G. A. Favarin ${ }^{1}$ \\ ${ }^{1 *}$ Corresponding author. University of Campinas, School of Agricultural Engineering/ Campinas - SP, Brasil. \\ E-mail: angelo@assiste.com.br | ORCID ID: https://orcid.org/0000-0002-3737-6082
}

\section{KEYWORDS}

performance

indicators,

maintenance

management,

harvesting operational capacity, agricultural mechanization.

\begin{abstract}
Recently, Brazilian agriculture and the mechanization process have been improved and developed, particularly in sugarcane cultivation. The developed processes should adopt suitable management practices in terms of the technical, economic, and operational logistical aspects. As a management tool, the present study aimed to measure the impact of the accumulated use of harvesters (life in $\mathrm{h}$ ) and agricultural productivity $\left(\mathrm{Mg} \cdot \mathrm{ha}^{-1}\right)$ on the harvesting operational capacity (HOC). Mathematical modeling was performed on data obtained from eight sugarcane production units, and equations corresponding to the HOC as a function of the harvester's life and the crop agricultural productivity were developed. The equation that best represented the phenomenon was selected. The values of the HOC depend on operational conditions and range from (17 to 44) $\mathrm{Mg} \cdot \mathrm{h}^{-1}$, thereby demonstrating significant operational and economic discrepancies. When the mean life of the harvester was $10,000 \mathrm{~h}$ and the mean productivity of the cane field was $80.0 \mathrm{Mg} \cdot \mathrm{ha}$ ${ }^{1}$, an $\mathrm{HOC}$ of $31.7 \mathrm{Mg} \cdot \mathrm{h}^{-1}$ was obtained. It was found that agricultural productivity is directly proportional to the HOC, whereas the harvester's life is inversely proportional to the HOC; the parameters are not linear in both cases.
\end{abstract}

\section{INTRODUCTION}

The growing demand for renewable fuels stimulated by environmental issues has led Brazil to become a major producer of renewable energy, which is supported by the wide expansion of sugarcane plantations (Saccharum spp.). This resulted in almost twice the area being harvested in 12 years, from 5.8 million hectares harvested in 2005 to approximately 8.4 million in 2019-2020 (Conab, 2020).

During this period, the use of agricultural machinery was essential to increase the plantation area, with special emphasis on the harvesting process, which was adapted to current legal requirements, such as law 11.241/2002. This law proposes the gradual elimination of sugarcane burning until 2031, thereby increasing the frequency of using harvesting equipment and making it necessary to adopt precise planning and management tools, which were not used systemically this evolution.

Bochtis et al. (2014) mentioned five tasks involved in the management of agricultural machinery, namely capacity planning (strategic level), task planning (tactical level), scheduling (operational level), path planning (operational level), and performance evaluation (evaluation level).

Banchi et al. (2019) stated that the mathematical modeling of harvesting parameters improves the use of management tools. Ripoli \& Ripoli (2009), corroborated by Teixeira (2013), studied the harvesting operational capacity (HOC), which is defined as the amount of work a harvester can perform as a function of time. Thus, the HOC can be considered as a management indicator that influences strategic and tactical levels, which require capacity and task planning.

Ripoli \& Ripoli (2009) reported that different factors affect the HOC, including operation management and agronomic, environmental, and technical conditions.

When studying the efficiency of forest harvesters in Nordic countries, Bergström et al. (2016) demonstrated that although the HOC is not influenced by the configuration of the plots, it corresponds to forest productivity. Bastos et al.

${ }^{1}$ University of Campinas, School of Agricultural Engineering/ Campinas - SP, Brasil.

Area Editor: Murilo Aparecido Voltarelli

Received in: 3-17-2020

Accepted in: 7-6-2020 
(2016) confirm this by reporting that an increase in the cane field productivity increases the HOC.

Ebadian et al., (2018) verified the parameters that influence the yield of bush willow crops (Salix L.). Similarly, when studying operational capacity in the harvesting of hybrid poplar (Populus L.), Eisenbies et al. (2017) found that crop productivity is the factor that has the greatest impact on operational capacity. Mathanker et al. (2015), Banchi et al. (2016), and Cervi et al. (2015) have corroborated this statement in similar sugarcane cultivation studies.

In addition to crop productivity, Hong et al. (2018) reported that mechanical wear of the equipment is another factor affecting the operational capacity. They stated that wear-related failures occur if it is not maintained well. Banchi et al. (2016) corroborated this statement by demonstrating that the time spent on maintenance increases with an increase in the fleet's accumulated life.

Although the HOC, life of a machine, and agricultural productivity correlate, these parameters must be measured and improved while considering multivariable functions, i.e., independent parameters. Thus, the objective of this study was to evaluate the influence of agricultural productivity and operating life on the HOC of mechanized self-propelled sugarcane harvesters by parameterizing a mathematical model.

\section{MATERIAL AND METHODS}

The data for this research were collected every month over four years using a fleet management software


crushing capacities (total cane harvested). The units were located in the southern-central region of Brazil.

The data were imported from the databases of the registration systems and transferred to spreadsheets; the variables were sugarcane production unit, manufacturer, and year of manufacture. The information collection cycle began after the harvester finished loading one wagon, using the harvester and wagon registering in this process. Then, the wagon was moved to the transfer yard. The load was transferred to the back of the road truck, which was later moved to the industrial unit's unloading yard. Here, it was weighed before and after entering to determine the liquid load.

The production unit, equipment used (model, fleet number, accumulated life, monthly use, and HOC), year and month of the report, and agricultural productivity of the cane field information was collected for the study.

To obtain the HOC as a function of the crop's agricultural productivity and the harvester's life, eight mathematical models (equations 1-8) were analyzed.

$$
\begin{aligned}
& H O C=a-c \times y^{e}-d \times x^{b} \\
& H O C=a-\frac{c}{y^{e}}-d \times x^{b} \\
& H O C=a-x^{b}-\frac{c}{y} \\
& H O C=63.5-x^{b}-\frac{c}{y} \\
& H O C=a+b \times x+c \times y \\
& H O C=a+b \times x+c \times x^{2}+d \times y+e \times y^{2}+f \times y \times x \\
& H O C=a+y^{c}-x^{b}
\end{aligned}
$$

$$
H O C=a-x \times \log (b)+\frac{c}{y}
$$

In which:

$$
\begin{aligned}
& \text { HOC - harvesting operational capacity }\left(\mathrm{Mg} \cdot \mathrm{h}^{-1}\right) \text {; } \\
& \mathrm{x} \text { - accumulated life of the equipment }(\mathrm{h}) ; \\
& \mathrm{y} \text { - productivity of the cane field }\left(\mathrm{Mg} \cdot \mathrm{ha}^{-1}\right) ; \\
& \mathrm{a} \text { - maximum HOC }\left(\mathrm{Mg} \cdot \mathrm{h}^{-1}\right) ; \\
& \text { b, c, d, e - constants fitted when modeling the data. }
\end{aligned}
$$

Mathematical concepts based on mechanical and agronomic parameters were used to define the aforementioned eight equations. Therefore, the equations emphasize that the HOC is directly proportional to agricultural productivity but not linear because the harvesting equipment demonstrate a mechanical limitation. In addition, the life parameter is inversely proportional to productivity but not linear owing to the mechanical and hydraulic wear of the equipment, which are not constant over its life. As the equations are empirical equations, eight models containing the aforementioned parameters were tested.

In equation 4, parameter "a" of equation 3 was replaced with a constant that represents the maximum HOC (optimal conditions of agricultural productivity and high speed). The other parameters are constants that were fitted when modeling the data. In equation 9, parameter "a" is obtained as a function of agricultural productivity, speed, cutting width, and elevator efficiency; the last parameter is influenced by the time dedicated to auxiliary operations.

$$
a=T C H \times \frac{V}{10} \times W \times E
$$

In which:

$\mathrm{V}$ - maximum average velocity $\left(\mathrm{km} \cdot \mathrm{h}^{-1}\right)$;

$\mathrm{TCH}$ - potential agricultural productivity of the crop $\left(\mathrm{Mg} \cdot \mathrm{ha}^{-1}\right)$;

$\mathrm{W}$ - cutting width (m);

*E - elevator efficiency (\%).

*Note: Elevator efficiency is the running time of the elevator divided by the running time of the engine.

Based on the history obtained from the harvesters' on-board computers, plant records, and practical field knowledge, a maximum operating speed of $5.5 \mathrm{~km} \cdot \mathrm{h}^{-1}$, potential agricultural productivity of $140 \mathrm{Mg} \cdot \mathrm{ha}^{-1}$, cutting width of $1.5 \mathrm{~m}$, and an elevator efficiency of $55 \%$ were adopted; the latter because the elevator is turned off during a part of the harvester's operating time for maneuvers and other auxiliary operations. By replacing the values in equation $9, a=63.5$.

The model parameters were defined based on multiple nonlinear regression using MATLAB ${ }^{\circledR}$ software. After parameterization, the models obtained were statistically analyzed using the methodology recommended by Montgomery \& Runger (2009). They adopted the ANOVA Table, which is based on the "Test F" hypothesis test, residual graphs, coefficient of determination $\left(\mathrm{R}^{2}\right)$, Akaike information criterion (AIC), and Bayesian information criterion (BIC). According to Motulsky \& 
Christopoulos (2003), these measures determine the model with the best fit and how well each model fits. In addition to these measures, the coefficient of determination $\left(\mathrm{R}^{2}\right)$ was also considered. It is obtained when the least squares method is used, which is suitable for many applications, particularly those involving continuous data.

\section{RESULTS AND DISCUSSION}

The study included two different models of harvesters, with years of manufacturing varying between
2010 and 2015, and life in hours varying between 0 and $21,000 \mathrm{~h}$. The models had a treadmill-type rolling system with a single cutting line and engine power ranging from (251 to 260$) \mathrm{kW}$.

A summary of the agronomic characteristics and equipment used in the six production units investigated is presented in Table 1, which presents data on the number of harvesters in terms of the manufacturer, their mean life in hours and age in years, and the cane field's annual production and agricultural productivity.

TABLE 1. Summary of data collected in the sugarcane production units (2015 basis).

\begin{tabular}{|c|c|c|c|c|c|c|c|c|}
\hline \multirow{2}{*}{ Unit } & \multicolumn{3}{|c|}{ Quantity of equipment } & \multirow{2}{*}{$\begin{array}{c}\text { Mean life } \\
\text { (h) }\end{array}$} & \multirow{2}{*}{$\begin{array}{c}\text { Age } \\
\text { (years) }\end{array}$} & \multirow{2}{*}{$\begin{array}{l}\text { Area } \\
\text { (ha) }\end{array}$} & \multirow{2}{*}{$\begin{array}{l}\text { Annual production } \\
\qquad(\mathrm{Mg})\end{array}$} & \multirow{2}{*}{$\begin{array}{l}\text { Productivity } \\
\left(\mathrm{Mg} \cdot \mathrm{ha}^{-1}\right)\end{array}$} \\
\hline & Manufacturer 1 & Manufacturer 2 & Total & & & & & \\
\hline A & 21 & 17 & 38 & 6,548 & 2 & 38,578 & $3,421,874$ & 88.7 \\
\hline $\mathrm{B}$ & 10 & 16 & 26 & 6,525 & 2 & 27,931 & $2,135,049$ & 76.4 \\
\hline $\mathrm{C}$ & 20 & 6 & 26 & 6,591 & 2 & 28,290 & $2,481,611$ & 87.7 \\
\hline $\mathrm{D}$ & 14 & 13 & 27 & 10,457 & 4 & 30,907 & $2,700,000$ & 87.4 \\
\hline $\mathrm{E}$ & 17 & 27 & 44 & 7,767 & 4 & 41,276 & $3,482,881$ & 84.4 \\
\hline $\mathrm{F}$ & 17 & 8 & 25 & 7,260 & 4 & 24,404 & $2,047,533$ & 83.9 \\
\hline Mean & & & & 7,525 & 3 & & & 84.7 \\
\hline S.D. & & & & 1,388 & 1.00 & & & 4.12 \\
\hline C.V. & & & & 18.4 & 33.3 & & & 4.9 \\
\hline
\end{tabular}

Note: S.D. - Standard deviation; C.V. - Coefficient of Variation

The eqs 1 to 8 were applied to the database, which consists of more than 16,000 records obtained from the production units studied, and the parameters of all the mathematical models were determined using non-linear regression tools.

The parameters obtained from each model and statistical analysis are presented in Table 2.

TABLE 2. Parameters of the models tested.

\begin{tabular}{|c|c|c|c|c|c|c|c|c|c|c|c|c|}
\hline \multirow{2}{*}{ Model } & \multicolumn{6}{|c|}{ Parameters } & \multirow{2}{*}{$\begin{array}{l}\text { Homog. } \\
\text { (p-value) }\end{array}$} & \multirow{2}{*}{$\begin{array}{c}\text { Shapiro- } \\
\text { Wilk } \\
\text { (p-value })\end{array}$} & \multirow{2}{*}{$\mathrm{R}(\%)$} & \multirow{2}{*}{$\mathrm{R}^{2}(\%)$} & \multirow{2}{*}{ AIC } & \multirow{2}{*}{$B I C$} \\
\hline & $\mathrm{a}$ & $\mathrm{b}$ & $\mathrm{c}$ & $\mathrm{d}$ & $\mathrm{e}$ & $\mathrm{f}$ & & & & & & \\
\hline 1 & 83.075 & 0.155 & 792.140 & 5.862 & -0.769 & & S & S & 52.9 & 28.0 & 6,873 & 6,902 \\
\hline 2 & 83.075 & 0.155 & 792.140 & 5.861 & -0.769 & & S & S & 53.2 & 28.3 & 6,873 & 6,902 \\
\hline 3 & 63.880 & 0.302 & 1300.000 & & & & NS & S & 77.1 & 59.4 & 5,853 & 5,872 \\
\hline 4 & & 0.308 & 1188.000 & & & & NS & S & 81.7 & 66.8 & 4,087 & 4,114 \\
\hline 5 & 17.250 & -0.001 & 0.236 & & & & NS & S & 61.3 & 37.6 & 6,684 & 6,704 \\
\hline 6 & -3.691 & -0.001 & 0.000 & 0.643 & 0.002 & 0.000 & S & S & 63.5 & 40.3 & 6,637 & 6,674 \\
\hline 7 & 22.960 & 0.300 & 0.725 & & & & NS & NS & 70.9 & 50.2 & 5,676 & 5,696 \\
\hline 8 & 55.360 & 1.001 & -0.001 & & & & NS & S & 62.6 & 39.2 & 6,656 & 6,676 \\
\hline
\end{tabular}

Note: Homog. - homogeneity; S - significant; NS - not significant.

The following are the data listed in Table 2:

Model - mathematical description being tested;

Parameters - dependent and independent variables;

- p-value of homogeneity - statistical index;

- p-value of normality (Shapiro-Wilk) - statistical index;

$-\mathrm{R}^{2}$ - coefficient of determination;

- AIC - Akaike information criterion

- BIC - Bayesian information criterion 
Based on the $\mathrm{R}^{2}$, AIC, and BIC, equation 4 was chosen because it demonstrated a better fit with an $\mathrm{R}^{2}$ of $66.8 \%$, a lower AIC and BIC of 4,087 and 4,114, respectively, and satisfying the homogeneity criterion. The other models were not chosen because of their lower
$\mathrm{R}^{2}$ and higher AIC and BIC.

The tests for homoscedasticity, independence, and normality were performed to evaluate the suitability of equation 4 , and the corresponding results are presented in Figure 1.

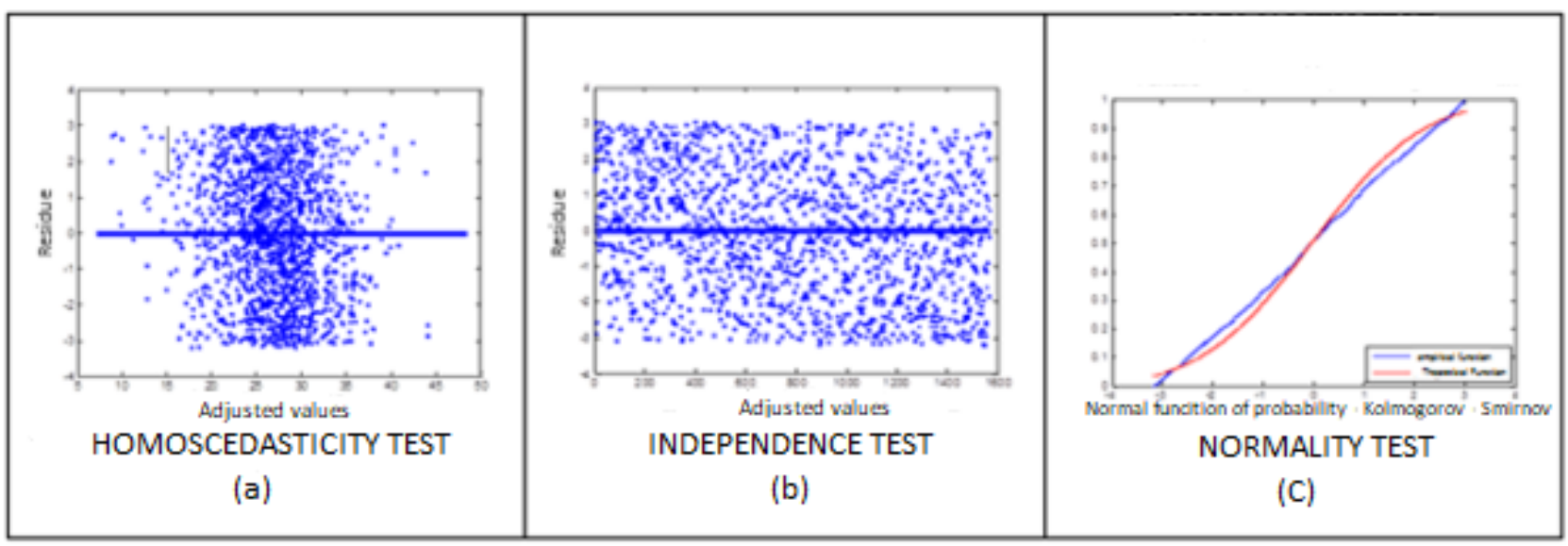

FIGURE 1. Analysis of equation 4.(a) Residue versus fitted values. (b) Residue versus order of collection of the data. (c) Cumulative function versus empirical function.

Figure 1(a) (homoscedasticity test) shows that the graph did not follow a random distribution with a mean of zero and constant amplitude, i.e., the assumption of homogeneity of variance was satisfied. Figure 1(b) (independence test) shows that the order of collection does not influence the dataset, i.e., the assumption that the errors are independent was satisfied. Figure 1(c) (normality test) shows a small difference between the empirical and theoretical distributions, i.e., the residues followed a normal distribution. Therefore, the equation of the chosen model can be defined as follows:

$$
H O C=63.5-x^{0.308}-\frac{1188}{y}
$$

In which:

HOC - harvesting operational capacity $\left(\mathrm{Mg} \cdot \mathrm{h}^{-1}\right)$;
63.5 - constant corresponding to the maximum HOC;

$\mathrm{x}=$ Accumulated life of the equipment (h);y = productivity of the can field $\left(\mathrm{Mg} \cdot \mathrm{ha}^{-1}\right)$.

In the Likelihood Ratio test, where the hypothesis of using the same parameters $\mathrm{b}$ and $\mathrm{c}$ for all production units was verified, it was found that the p-value was 2.2 16. Thus, hypothesis $\mathrm{H} 0$ is rejected and, consequently, hypothesis $\mathrm{H} 1$ is accepted. Therefore, each sugarcane production unit must be assigned individual parameters $b$ and c using, the mean of the parameters in the absence of the unit under study.

To verify and fit equation 10 , the HOC was simulated based on the actual capacity of five sugarcane production units in the database (Figure 2). 




(a)

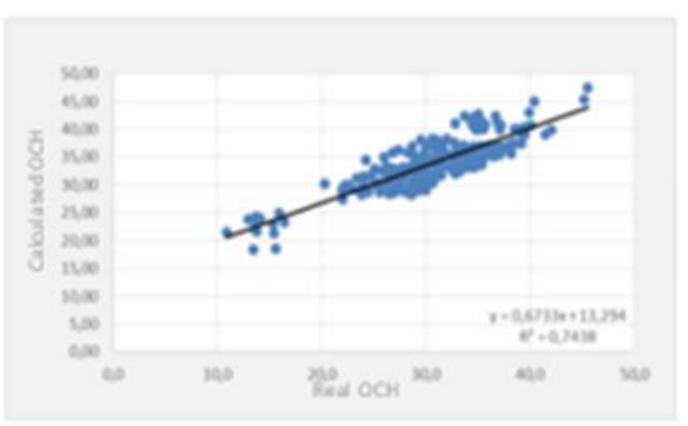

(c)

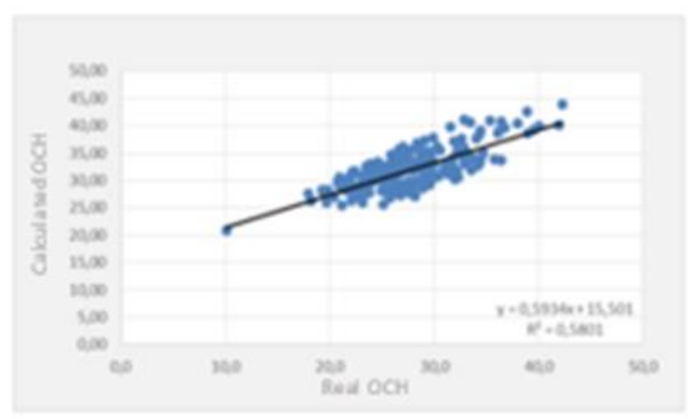

(e)

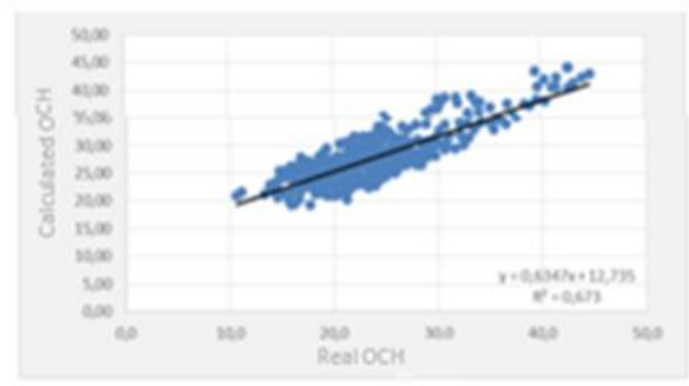

(b)

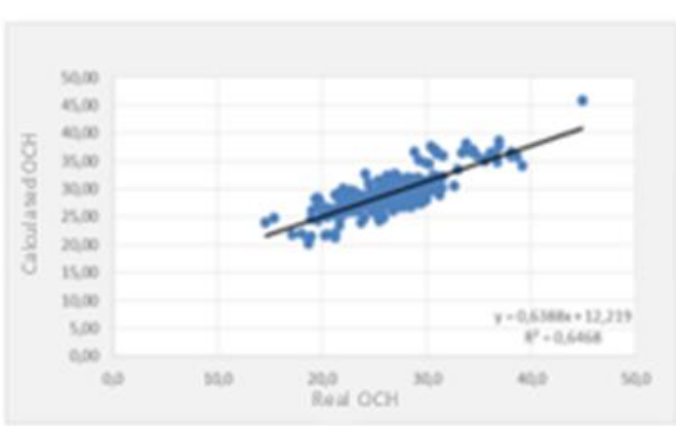

(d)

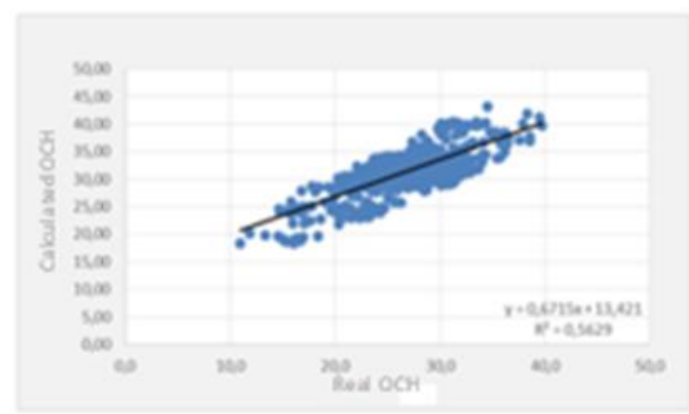

(f)

FIGURE 2. Estimation of HOC based on the actual capacity. (a) Overall. (b) Unit G-B. (c) Unit G-E. (d) Unit G-F. (e) Unit G-G. (f) Unit G-I.

The parameters $b$ and $c$ of equation 10 were obtained for each sugarcane production unit in the database using MATLAB software; the lowest and highest values observed are shown in bold (Table 3).

TABLE 3. Parameters $b$ and $c$ of equation 4 for each sugarcane production unit.

\begin{tabular}{|c|c|c|c|c|c|c|c|}
\hline \multirow{2}{*}{ Unit } & \multicolumn{2}{|c|}{ Parameters } & \multirow{2}{*}{$\begin{array}{l}\text { Homog. } \\
\text { (p-value) }\end{array}$} & \multirow{2}{*}{$\begin{array}{l}\text { Shapiro-Wilk test } \\
\text { (p-value) }\end{array}$} & \multirow{2}{*}{$\begin{array}{l}\mathrm{R}^{2} \\
(\%)\end{array}$} & \multirow{2}{*}{ AIC } & \multirow{2}{*}{ BIC } \\
\hline & $b$ & $c$ & & & & & \\
\hline A & 0.2890 & 1,354 & 0.0123 & 0.2542 & 67.7 & 1,230 & 1,240 \\
\hline B & 0.3188 & 1,372 & 0.0436 & 0.5182 & 81 & 301 & 307 \\
\hline $\mathrm{C}$ & 0.3298 & 1,040 & 0.0986 & 0.0032 & 61.4 & 871 & 880 \\
\hline D & 0.3341 & 645 & 0.0033 & 0.0831 & 63 & 421 & 428 \\
\hline $\mathrm{E}$ & 0.2767 & 1,876 & 0.0230 & 0.0950 & 52.5 & 560 & 590 \\
\hline $\mathrm{F}$ & 0.2713 & 2,047 & 0.7069 & 0.4477 & 71.8 & 121 & 125 \\
\hline Mean & 0.3033 & 1,389 & 0.14795 & 0.23357 & 66.2 & 584 & 595 \\
\hline
\end{tabular}


The variation in parameter c was due to the high variability of the Brazilian productive environment, where the soils exhibit high and low agricultural productivity ranging from (40 to 140$) \mathrm{Mg} \cdot \mathrm{ha}^{-1}$. In addition to agricultural productivity, management and systematization differ from one plant to another and influence the parameters of the HOC model.

Figure 3 shows a relationship between the HOC estimated by equation 10 with the mean of the parameters of the sugarcane production units and actual HOC because $\mathrm{R}^{2}$ was between $74.4 \%$ and $56.3 \%$. It is recommended that each unit be assigned its own parameters $b$ and $c$, but in their absence, the mean of the parameters may be used.

Using the mean of all the sugarcane production unit parameters, a response surface was generated for equation 10 (Figure 3 ) by considering the HOC as a function of the machine's operating life and sugarcane field agricultural productivity.

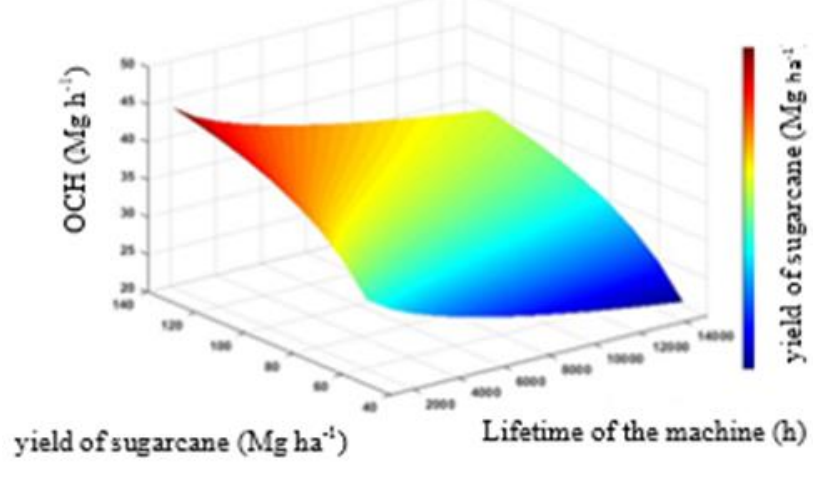

(a)

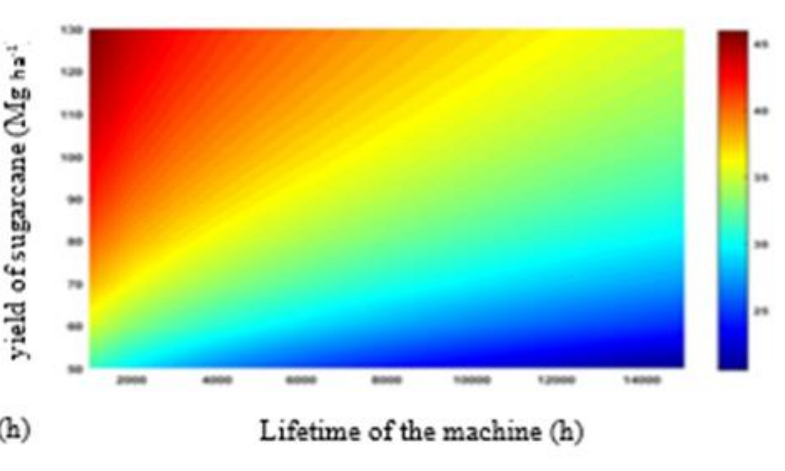

(b)

FIGURE 3. Response surface of equation 4. (a) HOC as a function of the machine's operating life and sugarcane field agricultural productivity in 3D. (b) HOC as a function of the machine's operating life and sugarcane field agricultural productivity.

Banchi et al. (2016) and Cervi et al. (2015) stated that the HOC is directly proportional to the productivity of the harvested area. Figure 3 shows that the HOC is directly proportional to the sugarcane field agricultural productivity, corroborating the aforementioned studies. In addition, Figure 3 shows that the HOC is inversely proportional to the machine's operating life. Thus, the relationship between $\mathrm{HOC}$ and variables studied is not linear.

By using equation 10 and parameters $b=0.3075$ and $\mathrm{c}=1188$ of equation 4 (Table 2), a simulation was performed by considering the $\mathrm{HOC}$ as a function of the machine's operating life and the sugarcane field agricultural productivity. Thus, a matrix was generated (Table 4).

TABLE 4. Matrix of $\mathrm{HOC}\left(\mathrm{Mg} \cdot \mathrm{h}^{-1}\right)$ as a function of the machine's operating life $(\mathrm{h})$ and sugarcane field agricultural productivity $\left(\mathrm{Mg} \cdot \mathrm{ha}^{-1}\right)$.

\begin{tabular}{|c|c|c|c|c|c|c|c|c|c|c|}
\hline \multirow{3}{*}{ Life $-x(h)$} & \multicolumn{9}{|c|}{$\operatorname{HOC}\left(\mathrm{Mg} \cdot \mathrm{h}^{-1}\right)$} & \multirow[b]{3}{*}{ Mean } \\
\hline & \multicolumn{9}{|c|}{ Productivity $-\mathrm{y}\left(\mathrm{Mg} \cdot \mathrm{ha}^{-1}\right)$} & \\
\hline & 50 & 60 & 70 & 80 & 90 & 100 & 110 & 120 & 130 & \\
\hline 2,000 & 29.4 & 33.3 & 36.2 & 38.3 & 39.9 & 41.3 & 42.3 & 43.2 & 44.0 & 38.7 \\
\hline 4,000 & 26.9 & 30.9 & 33.7 & 35.8 & 37.5 & 38.8 & 39.9 & 40.8 & 41.5 & 36.2 \\
\hline 6,000 & 25.2 & 29.2 & 32.0 & 34.1 & 35.8 & 37.1 & 38.2 & 39.1 & 39.8 & 34.5 \\
\hline 8,000 & 23.9 & 27.8 & 30.7 & 32.8 & 34.4 & 35.8 & 36.8 & 37.7 & 38.5 & 33.2 \\
\hline 10,000 & 22.8 & 26.7 & 29.5 & 31.7 & 33.3 & 34.6 & 35.7 & 36.6 & 37.4 & 32.0 \\
\hline 12,000 & 21.8 & 25.7 & 28.6 & 30.7 & 32.3 & 33.7 & 34.7 & 35.6 & 36.4 & 31.1 \\
\hline 14,000 & 20.9 & 24.9 & 27.7 & 29.8 & 31.5 & 32.8 & 33.9 & 34.8 & 35.5 & 30.2 \\
\hline 16,000 & 20.1 & 24.1 & 26.9 & 29.0 & 30.7 & 32.0 & 33.1 & 34.0 & 34.7 & 29.4 \\
\hline 18,000 & 19.4 & 23.4 & 26.2 & 28.3 & 30.0 & 31.3 & 32.4 & 33.3 & 34.0 & 28.7 \\
\hline 20,000 & 18.7 & 22.7 & 25.5 & 27.6 & 29.3 & 30.6 & 31.7 & 32.6 & 33.3 & 28.0 \\
\hline 22,000 & 18.1 & 22.1 & 24.9 & 27.0 & 28.7 & 30.0 & 31.1 & 32.0 & 32.7 & 27.4 \\
\hline 24,000 & 17.5 & 21.5 & 24.3 & 26.4 & 28.1 & 29.4 & 30.5 & 31.4 & 32.1 & 26.8 \\
\hline 26,000 & 17.0 & 20.9 & 23.7 & 25.9 & 27.5 & 28.8 & 29.9 & 30.8 & 31.6 & 26.2 \\
\hline Mean & 21.7 & 25.6 & 28.5 & 30.6 & 32.2 & 33.5 & 34.6 & 35.5 & 36.3 & 30.9 \\
\hline
\end{tabular}


The HOC varies between $17.0 \mathrm{Mg} \cdot \mathrm{h}^{-1}$ and 44.0 $\mathrm{Mg} \cdot \mathrm{h}^{-1}$ for an operating life between $0 \mathrm{~h}$ and 26,000 $\mathrm{h}$ and an agricultural productivity between $50 \mathrm{Mg} \cdot \mathrm{ha}^{-1}$ and $130 \mathrm{Mg} \cdot \mathrm{ha}^{-1}$, with a mean value of $34.1 \mathrm{Mg} \cdot \mathrm{h}^{-1}$ for 6,000 $\mathrm{h}$ of operating life and an agricultural productivity of 80 $\mathrm{Mg} \cdot \mathrm{ha}^{-1}$. These values corroborate those reported by Ripoli \& Ripoli (2009), whose experiment resulted in a HOC ranging from (28.0 to 35.0) $\mathrm{Mg} \cdot \mathrm{h}^{-1}$. By varying the agricultural productivity from (63 to 95$) \mathrm{Mg} \cdot \mathrm{ha}^{-1}$, the results reported in this study corroborate those of Teixeira (2013), who studied the HOC by agricultural productivity range, and obtaining a mean HOC of 24.2 $\mathrm{Mg} \cdot \mathrm{h}^{-1}$ for a productivity range between $71 \mathrm{Mg} \cdot \mathrm{ha}^{-1}$ and $100 \mathrm{Mg} \cdot \mathrm{ha}^{-1}$, and $31.0 \mathrm{Mg} \cdot \mathrm{h}^{-1}$ for a productivity range between $101 \mathrm{Mg} \cdot \mathrm{ha}^{-1}$ and $135 \mathrm{Mg} \cdot \mathrm{ha}^{-1}$.

Ripoli \& Ripoli (2009) reported that while the HOC is dependent on the speed of operation and the system's management, it is primarily dependent on the crop's agricultural productivity $\left(\mathrm{Mg} \cdot \mathrm{ha}^{-1}\right)$ and harvester's age (life in h). This was confirmed by Bastos et al. (2016), who varied the productivity from (73.4 to 99.5$) \mathrm{Mg} \cdot \mathrm{h}^{-1}$ and obtained a $31.5 \%$ increase in the HOC.

The HOC results obtained in this study are similar to those of Mathanker et al. (2015), who obtained an HOC of $30.0 \mathrm{Mg} \cdot \mathrm{h}^{-1}$ at a speed of $5.0 \mathrm{~km} \cdot \mathrm{h}^{-1}$.

From Table 4, it can be observed that the percentage variation of HOC as a function of harvester's life reaches $40 \%$ with a mean value ranging from (38.7 to 26.2) $\mathrm{Mg} \cdot \mathrm{h}^{-1}$. The estimation of HOC while considering an initial productivity of $50 \mathrm{Mg} \cdot \mathrm{ha}^{-1}$ and a final productivity of $130 \mathrm{Mg} \cdot \mathrm{ha}^{-1}$ resulted in a variation of $47 \%$, thereby demonstrating that the HOC is significantly influenced by the two parameters analyzed.

According to American Society of Agricultural and Biological Engineers (ASABE) (ASAE D496.3, 2011), the HOC is defined in terms of cutting speed $\left(\mathrm{km} \cdot \mathrm{h}^{-1}\right)$, cutting width $(\mathrm{m})$, field efficiency, and crop productivity $\left(\mathrm{Mg} \cdot \mathrm{ha}^{-1}\right)$. When comparing the parameters adopted by ASABE (ASAE D496.3, 2011) with those of equation 10 (Figure 3), three differences may be noted. The first refers to the lifetime of the equipment; according to Hong et al. (2018) and confirmed by the data presented in Table 4, this parameter significantly influences the HOC because with the accumulation of worked hours, the equipment suffers mechanical wear that affects the recovery of its cutting speed. In addition, the HOC equation proposed by ASABE (ASAE D496.3, 2011) is not specific to the cultivation of sugarcane. Further, it represents linearity, i.e., this equation does not consider the limitation of harvest depending on the productivity of the sugarcane field and equipment.

Several studies, such as Ripoli \& Ripoli (2009), Banchi et al. (2012), Teixeira (2013), and Ramos et al. (2016), report that the HOC may be influenced by various aspects, such as agronomic (crop's agricultural productivity), operational (speed and skill of the operator), or agricultural systematization (parallelism between planting lines, line lengths, and topography). Furthermore, this study confirms that the mechanical condition of the harvester is an additional aspect, which is, in turn, influenced by the harvester's age (life in h).

\section{CONCLUSIONS}

Several equations for modeling the HOC of sugarcane harvesters were proposed, and the most appropriate model was identified. Thus, it was noted that HOC is influenced by the agricultural productivity and life of the harvester. Further, the HOC can affect the decisions corresponding to harvest management.

Because of the variation in the amplitude of HOC according to the agronomic and mechanical conditions of the equipment, it is concluded that the model should be validated for each case, but in the absence of a specific model, the model proposed in this study can be used.

The relationship between the HOC and agricultural productivity was observed to be directly proportional but not linear owing to mechanical limitations of the harvester. Further, the HOC is inversely proportional to the life of the equipment but not linear.

The model established in this study was multivariable, as it was based on independent variables such as the life of the equipment and agricultural productivity. Although the proposed model represents the HOC and its variations, future studies may improve the model by including other factors.

\section{REFERENCES}

ASAE - American Society of Agricultural and Biological Engineers (2011) Agricultural machinery management data ASAE D496.3. In: ASABE standards.

Banchi AD, Garcia AG, Grespan A, Albieiro D, Favarin LGA, Galvão CB (2019) Custo Operacional da colhedora de cana-de-açúcar em função da produtividade agrícola e idade da colhedora. Revista Brasileira de Engenharia Agrícola e Ambiental 27(07):552-557.

Banchi AD, Lopes JR, Ferreira VA, Favarin LGA (2016) Produção e rendimento de colhedoras de cana-de-açúcar. Revista Agrimotor 1(101):23-24.

Banchi AD, Lopes JR, Martins JMS, Dimase M (2012) Capacidade operacional de colheita de cana-de-açúcar modelagem matemática em função da produtividade agrícola e da vida da máquina. Revista Agrimotor $77(1): 42-45$.

Bastos KJJZ, Landell MGA, Miranda ES (2016) Influência da produtividade da cana-de-açúcar no custo do corte mecanizado. Revista Ipecege 02(4):42-59.

DOI: http://dx.doi.org/10.22167/r.ipecege.2016.4.42

Bergström D, Fulvio FD, Nuutinen Y (2016) Effect of Forest Structure on Operational Efficiency of a BundleHarvester System in Early Thinnings. Croatian Journal of Forest Engeneering:37-49.

Bochtis DD, Sorensen CGC, Busato P (2014) Advances in agricultural machinery management: A review.

Biosystems Engineering 126:69-81. DOI:

http://dx.doi.org/10.1016/j.biosystemseng.2014.07.012 
Cervi RG, Esperancini TMS, Silva HOF, Isler PR, Oliveira PA (2015) Avaliação do desempenho operacional da colheita e transbordo de cana-de açúcar (saccharum spp.). Energia na Agricultura 30(3):232-241. DOI:

http://dx.doi.org/10.17224/EnergAgric.2015v30n3p232-241

CONAB - Companhia Nacional de Abastecimento (2020)

Acompanhamento da safra brasileira: cana-de-açúcar, safra 2019/2020. CONAB.

Ebadian M, Shedden ME, Webb E, Sokhansaj S, Eisenbies M, Volk T, Heavey J, Hallen K (2018) Impact of Parcel Size, Field Shape, Crop Yield, Storage Location, and Collection Equipment on the Performance of SinglePass Cut-and-Chip Harvest System in Commercial Shrub Willow Fields. BioEnergy Research 11: 364-381. DOI: https://doi.org/10.1007/s12155-018-9902-7.

Eisenbies MH, Volk TA, Espinozza J, Gants C, Himes A, Posselius J, Shuren R, Stanton B, Summers B (2017)

Biomass, spacing and planting design influence cut-and-chip harvesting in hybrid poplar. Biomass and Bioenergy 106:182190. DOI: http://dx.doi.org/10.1016/j.biombioe.2017.09.003

Hong W, Cai W, Wang S, Tomovic MM (2018)

Mechanical wear debris feature, detection, and diagnosis: A review. Chinese Journal of Aeronautics 31(5):867-882. DOI: https://doi.org/10.1016/j.cja.2017.11.016
Mathanker SK, Gan H, Buss JC, Lawson B, Hansen AC, Ting KC (2015) Power requirements and field performance in harvesting energycane and sugarcane. Biomass and Bioenergy 75:227-234.

DOI: https://doi.org/10.1016/j.biombioe.2015.02.025.

Montgomery DC, Runger GC (2009) Estatística aplicada e probabilidade para engenheiros. Rio de Janeiro, LTC, 4 ed.

Motulsky H, Christopoulos A (2003) Fitting models to biological data using linear and nonlinear regression: a practical guide to curve fitting. San Diego, GraphPad Software, 4 ed. 351p.

Ramos CRG, Lanças KP, Santos RS, Silva RL (2016) Perdas e impurezas na colheita mecanizada de cana-de-açúcar utilizando diferentes configurações de trabalho da colhedora. Revista Energia na agricultura 31(4):317-327. DOI: http://dx.doi.org/10.17224/EnergAgric.2016v31n4p317-327

Ripoli TCC, Ripoli MLC (2009) Biomassa de cana-de-açúcar: colheita, energia e ambiente. Escola Superior de Agricultura "Luiz de Queiroz", Universidade de São Paulo.

Teixeira FLS (2013) Custos da colheita mecanizada de cana-de-açúcar em três faixas de produtividade. 40p. Dissertação Mestrado, Piracicaba, Escola Superior de Agricultura "Luiz de Queiroz", Universidade de São Paulo. 